\title{
Rethinking the residential urban environment in Iraq - literature review
}

\author{
Al-Shaibani Alaa Abdali Hanoon*, and Dhumad Kadhim Faris Dhumad \\ Baghdad University, Iraq
}

\begin{abstract}
Is a new study to understand the residential architectural environment in Iraq through survey of a series of international, regional and local research and studies related to the residential architectural environment (1991-2019), which approximates 20 studies. the general problem the absence of a clear theoretical scenario that describes the architectural residential environment for the circumstances experienced by the Iraq now. Therefore, the aim of study to give an accurate description and definition of vocabulary and concepts through Theoretical conception to achieve a broader understanding of the residential architectural environment in Iraq (definition of the residential living environment, Housing satisfaction standards and description of the problem of informal housing). This is done by introduction of a three-stage model research, and classification of three items (Housing Satisfaction, Urban Context, Architectural Formation).The results of this study are a set of factors are related to spatial objective reasons for different architectural residential environments are similar the Iraq circumstances. and the research put its observations in a table divided into three axes, to archived aim.
\end{abstract}

\section{Introduction}

Housing structure and related problems have intensified in Iraq since 2003 due to rapidly rising housing needs, non-compliance with laws and regulations, and ineffective government programs and policies in the face of growing cities, reflecting declining living standards in many cities. cities, Since the creation of the Iraqi state for over 100 years, many housing plans and programs aimed at solving housing problems and access to a living environment meet the objective needs of the population, but most of these strategies and programs have not been implemented due to the lack of an integrated approach in aspects. This study presents a new concept for understanding the residential architectural environment in Iraq by reformulating and identifying the components of the living environment in them and identifying the most important problems and defining the principles of composition, and then Develop solutions that contribute to the provision of decent housing. Therefore, the importance of the study lies in the study of the basic vocabulary and factors that influenced the formation of the living environment in the Middle East, Middle East, Eastern Europe and the West, as well as in Asia such as China, India and Malaysia. What constitutes a model of strategic vision, built on an objective basis in the process of redefining the components of the living environment, and how to reflect the achievement of comfort in a residential area based 
on the definition of the components of the principles of residential architecture applied in the Middle East and in Iraq in particular W, in (Iraq).

Studies of the first group, Classification of residential architectural environment in Iraq.

concerned the concept of residential architectural environment [1], [2], [3], [4], [5], [6], [7], [8], [9], [10]. and focused on the meanings and form of residential architecture. Accordingly, they presented a set of issues related to socio-cultural factors and housing satisfaction standards that directly influence the formation of a residential architectural environment. where one could develop a conceptual formula entitled "Problems of Formation", which would later become the basis for the development of a conceptual framework to paraphrase the residential architectural environment. It was like that. in the table (1)

Group Two Studies, Housing Satisfaction Standards or Socially Acceptable Housing.

are devoted to housing policies, programs and standards [11], [12], [13], [14], [15], [16], [17], [18].aimed at solving the housing crisis in general. They referred to housing programs that could reduce the size of housing problems in different countries and establish housing criteria that can be adopted in addressing the challenges of the residential architectural environment in Iraq. It was like that. in the table (2)

Third group studies, Informal housing.

focused on informal and casual housing [19], [20], [21], [22], [23], [24], [25]. These are the most common housing problems in Iraq. At present, due to informal and casual housing, the urban environment does not provide a decent life for both individuals and families and society as a whole. The Researcher was able to find a new formula of knowledge (perspectives of problems) to form a conceptual framework in the future to develop appropriate solutions to describe problems, as well as through research in table (3).

1.4 A summary of the concepts and terminology that make up the residential architectural environment. Research - Model and Strategy Formulation for Redeveloping the Architectural Environment in Iraq By defining and understanding the components of this environment, it is based on concepts and factors, Seven factors have been identified (Social and Cultural Factors, Economic, Environmental and Climate, Geographic, Political and Security, Subjective or psychological planning) and six concepts (Concept of architectural emergence, Housing problems, Housing standards, Housing satisfaction and decent housing, Programs and strategies, Identity and transformation) that shape the living environment in a step towards solving the research problem by redefining the residential architectural environment and understanding its characteristics.

\section{Ways to solve the identified problems}

The study also shows that the problem under study will go through three main stages in order to solve it based on the classification. These classifications have been ordered according to previous studies and a diagram which is shown in Figure 1 below These classifications are considered as the core for solving the research problem, studying the architectural habitat in Iraq, clarifying the activities taking place in the residential environment, identifying them and further making planning and urban planning decisions after familiarizing themselves with the existing problems through the approved standards and achieving the main problem in the residential environment ... The study identified three categories of management studied. The researchers prepared tables indicating the most important concepts and factors related to the residential architectural environment, which were explained by previous studies and the reasons for their appearance, as well as the observations of the researchers as part of the action plan to analyze the selected studies. As shown in (Table 1,2,3). 1. Residential architectural environment. 2. Criteria for satisfaction with housing or socially acceptable housing. 3. Informal housing. 
Table 1. Showing summary of research related to Architectural formation and the environment

\begin{tabular}{|c|c|c|c|c|c|}
\hline $\begin{array}{c}\text { Inde } \\
\mathbf{x} \\
\end{array}$ & Study & $\begin{array}{l}\text { Related } \\
\text { Factors }\end{array}$ & $\begin{array}{l}\text { Causes of the } \\
\text { Phenomenon }\end{array}$ & $\begin{array}{c}\text { Related } \\
\text { Concepts }\end{array}$ & Research Notes \\
\hline A1 & $\begin{array}{l}\text { (Mariam Yakub, 2017) } \\
\text { "Open Source } \\
\text { Architecture: } \\
\text { Redefining Residential } \\
\text { Architecture in } \\
\text { Islamabad". }\end{array}$ & $\begin{array}{l}\text { Related to } \\
\text { climatic } \\
\text { and cultural } \\
\text { factors that } \\
\text { constitute } \\
\text { the } \\
\text { residential } \\
\text { environmen } \\
\text { t and } \\
\text { provide } \\
\text { housing } \\
\text { options }\end{array}$ & $\begin{array}{l}\text { The need to } \\
\text { address the } \\
\text { shortage of } \\
\text { units and } \\
\text { control the } \\
\text { residential } \\
\text { environment } \\
\text { according to } \\
\text { specific } \\
\text { architectural } \\
\text { standards for } \\
\text { design }\end{array}$ & $\begin{array}{l}\text { Related to } \\
\text { the concept } \\
\text { of } \\
\text { residential } \\
\text { architectura } \\
1 \text { formation }\end{array}$ & $\begin{array}{l}\text { There is no objective } \\
\text { definition of the } \\
\text { residential environment, } \\
\text { although the four options } \\
\text { for residents are defined. }\end{array}$ \\
\hline A2 & $\begin{array}{l}\text { (Tatiana Vadimovna, } \\
\text { 2017) " } \\
\text { ADAPTATION OF } \\
\text { THE LIVING } \\
\text { ENVIRONMENT OF } \\
\text { MASS micro districts } \\
\text { TYPICAL } \\
\text { DEVELOPMENT TO } \\
\text { MODERN SOCIAL } \\
\text { ECONOMIC } \\
\text { PROCESSES". } \\
\end{array}$ & $\begin{array}{l}\text { Social and } \\
\text { environmen } \\
\text { tal factors }\end{array}$ & $\begin{array}{l}\text { The need for } \\
\text { the } \\
\text { environment } \\
\text { social } \\
\text { housing } \\
\text { instead of } \\
\text { industrial } \\
\text { residential } \\
\text { environment }\end{array}$ & $\begin{array}{l}\text { Concept of } \\
\text { residential } \\
\text { formation } \\
\text { and } \\
\text { residential } \\
\text { standards }\end{array}$ & $\begin{array}{l}\text { It is necessary to identify } \\
\text { the research items which } \\
\text { constitute the backbone } \\
\text { of the residential } \\
\text { architecture. }\end{array}$ \\
\hline A3 & $\begin{array}{l}\text { (Zhanna, 1993) } \\
\text { "Conditions for the } \\
\text { formation of low-rise } \\
\text { residential buildings } \\
\text { for high-density urban } \\
\text { development (on the } \\
\text { example of Iraq) b" }\end{array}$ & $\begin{array}{l}\text { Climate } \\
\text { and social } \\
\text { factors }\end{array}$ & $\begin{array}{l}\text { Formation of } \\
\text { low rise } \\
\text { residential } \\
\text { buildings for } \\
\text { high density } \\
\text { development }\end{array}$ & $\begin{array}{l}\text { Related to } \\
\text { the concept } \\
\text { of problems } \\
\text { of } \\
\text { architectura } \\
1 \text { formation }\end{array}$ & $\begin{array}{l}\text { The study did not } \\
\text { address residential } \\
\text { criteria in determining } \\
\text { the levels of residential } \\
\text { buildings. }\end{array}$ \\
\hline A4 & $\begin{array}{l}\text { (A. } \\
\text { GHAFFARIANHOSE } \\
\text { INI etc., 2014) "The } \\
\text { Essence of Malay } \\
\text { Vernacular Houses: } \\
\text { Analysis of the Socio- } \\
\text { Cultural". }\end{array}$ & $\begin{array}{l}\text { Social, } \\
\text { cultural and } \\
\text { climatic } \\
\text { factors }\end{array}$ & $\begin{array}{l}\text { The nature of } \\
\text { the } \\
\text { population's } \\
\text { association } \\
\text { with daily } \\
\text { behavior }\end{array}$ & $\begin{array}{l}\text { Related to } \\
\text { the concept } \\
\text { of } \\
\text { residential } \\
\text { architectura } \\
1 \text { formation }\end{array}$ & $\begin{array}{l}\text { Adopting the study as a } \\
\text { way of life and a work } \\
\text { methodology to assess } \\
\text { the assessment of } \\
\text { different environments }\end{array}$ \\
\hline A5 & $\begin{array}{l}\text { (MAZDAK } \\
\text { ARMSTRONG, 2017) } \\
\text { "evolution of } \\
\text { Residential Building in } \\
\text { Iran based on } \\
\text { Organization of space" }\end{array}$ & $\begin{array}{l}\text { Related to } \\
\text { the } \\
\text { historical } \\
\text { and } \\
\text { culturalfact } \\
\text { ors of a } \\
\text { society } \\
\end{array}$ & $\begin{array}{l}\text { Transition to } \\
\text { the concept of } \\
\text { mass } \\
\text { construction } \\
\text { and loss of } \\
\text { fertility and } \\
\text { social values }\end{array}$ & $\begin{array}{l}\text { Concept of } \\
\text { residential } \\
\text { formation } \\
\text { and } \\
\text { residential } \\
\text { standards }\end{array}$ & $\begin{array}{l}\text { The resulting urban } \\
\text { context has eroded the } \\
\text { true spirit of architecture } \\
\text { in Iran and has been } \\
\text { reflected in the social } \\
\text { relations of the } \\
\text { inhabitants. }\end{array}$ \\
\hline A6 & $\begin{array}{l}\text { (Jiboye Est, 2014) } \\
\text { Significance of house- } \\
\text { type as determinant of } \\
\text { residential quality in } \\
\text { Osogbo, Southwest } \\
\text { Nigeria }\end{array}$ & $\begin{array}{l}\text { Social } \\
\text { factors and } \\
\text { factors } \\
\text { related to } \\
\text { the quality } \\
\text { factor of } \\
\text { the same } \\
\text { person }\end{array}$ & $\begin{array}{l}\text { The desire of } \\
\text { the } \\
\text { inhabitants is } \\
\text { to provide } \\
\text { them with } \\
\text { adequate } \\
\text { housing } \\
\text { through } \\
\text { various } \\
\text { traditional } \\
\text { and } \\
\text { contemporary } \\
\text { houses }\end{array}$ & $\begin{array}{l}\text { Related to } \\
\text { the } \\
\text { individualizat } \\
\text { ion of the } \\
\text { formation } \\
\text { and the re- } \\
\text { formulation } \\
\text { of the } \\
\text { residential } \\
\text { environment } \\
\text { and the } \\
\text { standards of } \\
\text { residential } \\
\text { satisfaction }\end{array}$ & $\begin{array}{l}\text { The concept of } \\
\text { residential quality is } \\
\text { inherent to the concept of } \\
\text { evaluation and through } \\
\text { it, housing satisfaction or } \\
\text { socially acceptable } \\
\text { housing is achieved. }\end{array}$ \\
\hline
\end{tabular}


Table 1. Continued

\begin{tabular}{|c|c|c|c|c|c|}
\hline A7 & $\begin{array}{l}\text { (Mohammed Thajil, } \\
\text { 2005)"THE SOCIAL } \\
\text { INFLUENCE OF THE } \\
\text { CHANGMENT OF } \\
\text { THE HOUSE FORM } \\
\text { (BAGHDAD CITY)" }\end{array}$ & $\begin{array}{l}\text { Social and } \\
\text { aesthetic } \\
\text { factors }\end{array}$ & $\begin{array}{l}\text { Because of } \\
\text { social impact, } \\
\text { the shape of } \\
\text { housing } \\
\text { changes. }\end{array}$ & $\begin{array}{l}\text { Related to } \\
\text { the concept } \\
\text { of } \\
\text { architectura } \\
1 \text { formation } \\
\text { and } \\
\text { formation } \\
\text { standards }\end{array}$ & $\begin{array}{l}\text { Changing the shape of } \\
\text { housing is associated } \\
\text { with architectural and } \\
\text { design characteristics } \\
\text { linked to social changes } \\
\text { and economic level. }\end{array}$ \\
\hline A8 & $\begin{array}{l}\text { (Aysu Akalin, 2009) } \\
\text { "Architecture and } \\
\text { engineering students' } \\
\text { evaluations of house } \\
\text { facades: Preference, } \\
\text { complexity and } \\
\text { impressiveness". }\end{array}$ & $\begin{array}{l}\text { Social and } \\
\text { environmen } \\
\text { tal } \\
\text { factors/psyc } \\
\text { hological } \\
\text { and } \\
\text { subjective } \\
\text { factors }\end{array}$ & $\begin{array}{l}\text { Reflecting the } \\
\text { behavior of } \\
\text { individual } \\
\text { identity by } \\
\text { the } \\
\text { inhabitants } \\
\text { themselves, } \\
\text { where they } \\
\text { change the } \\
\text { facades of } \\
\text { their homes. }\end{array}$ & $\begin{array}{l}\text { Related to } \\
\text { the concept } \\
\text { of problems } \\
\text { of } \\
\text { architectura } \\
1 \text { formation } \\
\text { and future } \\
\text { prospects } \\
\text { of } \\
\text { formation }\end{array}$ & $\begin{array}{l}\text { The preference is a } \\
\text { general urban context, as } \\
\text { well as individual } \\
\text { behavior that arises in } \\
\text { the inhabitants and } \\
\text { crystallizes into reality in } \\
\text { changing the facades of } \\
\text { houses, individually, } \\
\text { reflecting their individual } \\
\text { identity. }\end{array}$ \\
\hline A9 & $\begin{array}{l}\text { (Omar Al-Hafeet, } \\
\text { 2018) "A systematic } \\
\text { assessment of } \\
\text { architectural } \\
\text { approaches to solving } \\
\text { the Iraqi housing } \\
\text { problem." }\end{array}$ & $\begin{array}{l}\text { Housing } \\
\text { satisfaction } \\
\text { criteria and } \\
\text { subjective } \\
\text { factors }\end{array}$ & $\begin{array}{l}\text { Lack of a } \\
\text { preferred } \\
\text { architectural } \\
\text { style for } \\
\text { residents }\end{array}$ & $\begin{array}{l}\text { Architectur } \\
\text { al design } \\
\text { concept and } \\
\text { housing } \\
\text { satisfaction }\end{array}$ & $\begin{array}{l}\text { The aim of the study is } \\
\text { socially acceptable } \\
\text { housing as the most } \\
\text { important factor in the } \\
\text { residential architectural } \\
\text { environment }\end{array}$ \\
\hline A10 & $\begin{array}{l}\text { (Zhdanova Irina } \\
\text { Viktorovna, 2013) } \\
\text { "Architectural } \\
\text { methods for assessing } \\
\text { and improving the } \\
\text { consumer properties of } \\
\text { the living } \\
\text { environment". }\end{array}$ & $\begin{array}{l}\text { Social and } \\
\text { aesthetic } \\
\text { factors } \\
\text { Planning } \\
\text { factors }\end{array}$ & $\begin{array}{l}\text { Development } \\
\text { of a system } \\
\text { for assessing } \\
\text { the quality of } \\
\text { architectural } \\
\text { and spatial } \\
\text { solutions of } \\
\text { the living } \\
\text { environment }\end{array}$ & $\begin{array}{l}\text { Housing } \\
\text { standards } \\
\text { Housing } \\
\text { satisfaction } \\
\text { and decent } \\
\text { housing }\end{array}$ & $\begin{array}{l}\text { Improving living } \\
\text { conditions is associated } \\
\text { with improving the } \\
\text { functional characteristics } \\
\text { of residential buildings } \\
\text { through the creation of } \\
\text { new functional } \\
\text { relationships }\end{array}$ \\
\hline
\end{tabular}

Table 2. Summary Research on Housing Standards, Programs and Policies

\begin{tabular}{|l|l|l|l|l|l|}
\hline Index & \multicolumn{1}{|c|}{ Study } & $\begin{array}{c}\text { Related } \\
\text { Factors }\end{array}$ & $\begin{array}{l}\text { Causes of the } \\
\text { Phenomenon }\end{array}$ & $\begin{array}{c}\text { Related } \\
\text { Concepts }\end{array}$ & \multicolumn{1}{c|}{ Research Notes } \\
\hline B1 & $\begin{array}{l}\text { (Tiwari Est, 2016) } \\
\text { "Housing Markets } \\
\text { and Housing } \\
\text { Policies in India" }\end{array}$ & $\begin{array}{l}\text { Economic } \\
\text { factors as } \\
\text { well as } \\
\text { housing } \\
\text { policies and } \\
\text { programs }\end{array}$ & $\begin{array}{l}\text { Residential growth, } \\
\text { living conditions, } \\
\text { lack of financial } \\
\text { resources and poor } \\
\text { program } \\
\text { implementation }\end{array}$ & $\begin{array}{l}\text { Related to } \\
\text { the concept } \\
\text { of problem } \\
\text { prospects }\end{array}$ & $\begin{array}{l}\text { Make decent housing } \\
\text { a constitutional right } \\
\text { and address programs } \\
\text { and policies with } \\
\text { objective programs }\end{array}$ \\
\hline B2 & $\begin{array}{l}\text { (Onyemaechi Est, } \\
\text { 2016) "Motives and } \\
\text { Motivation for } \\
\text { Implementation of } \\
\text { Public Private } \\
\text { Partnerships (PPPs) } \\
\text { in Housing } \\
\text { Provision in } \\
\text { Nigeria" }\end{array}$ & $\begin{array}{l}\text { Economic } \\
\text { factors and } \\
\text { political } \\
\text { factors }\end{array}$ & $\begin{array}{l}\text { Addressing the } \\
\text { acute shortage of } \\
\text { housing units and } \\
\text { the desire for } \\
\text { partnership } \\
\text { between the public } \\
\text { and private sectors }\end{array}$ & $\begin{array}{l}\text { Related to } \\
\text { the concept } \\
\text { of problem } \\
\text { prospects } \\
\text { and concept } \\
\text { of } \\
\text { partnership }\end{array}$ & $\begin{array}{l}\text { The relationship between } \\
\text { the public and private } \\
\text { sectors is one of the most } \\
\text { important elements of } \\
\text { facing the housing crisis } \\
\text { in an approved } \\
\text { residential environment. } \\
\text { The partnership is based } \\
\text { on the desire of both } \\
\text { parties to develop the } \\
\text { residential environment } \\
\text { and achieve profits. }\end{array}$ \\
\hline
\end{tabular}


Table 2. Continued

\begin{tabular}{|c|c|c|c|c|c|}
\hline B3 & $\begin{array}{l}\text { (Huda Ahmed, } \\
\text { 2015) "National } \\
\text { housing policies in } \\
\text { Iraq" }\end{array}$ & $\begin{array}{l}\text { Economic } \\
\text { factors, } \\
\text { political factors } \\
\text { and housing } \\
\text { standards }\end{array}$ & $\begin{array}{l}\text { Because of the } \\
\text { failure to implement } \\
\text { the policies adopted } \\
\text { to resolve the } \\
\text { housing crisis in } \\
\text { Iraq }\end{array}$ & $\begin{array}{l}\text { Related to the } \\
\text { individual } \\
\text { housing } \\
\text { problems as } \\
\text { well as } \\
\text { policies and } \\
\text { programs }\end{array}$ & $\begin{array}{l}\text { Iraqi policies and } \\
\text { programs must be } \\
\text { based on a future } \\
\text { vision based on the } \\
\text { reality of the } \\
\text { country. }\end{array}$ \\
\hline B4 & $\begin{array}{l}\text { (Khalaf A. Ali, } \\
\text { est,2017) "Planning } \\
\text { for Affordable } \\
\text { Housing Units in } \\
\text { Dohuk / Iraq, } \\
\text { Survey" }\end{array}$ & $\begin{array}{l}\text { Economic and } \\
\text { financial } \\
\text { factors as well } \\
\text { as factors } \\
\text { related to } \\
\text { housing } \\
\text { indicators such } \\
\text { as family } \\
\text { income }\end{array}$ & $\begin{array}{l}\text { Because of } \\
\text { economic factors } \\
\text { and investment } \\
\text { trends as well as } \\
\text { laws that do not } \\
\text { meet ambition }\end{array}$ & $\begin{array}{l}\text { Related to the } \\
\text { concept of } \\
\text { problem } \\
\text { prospects }\end{array}$ & $\begin{array}{l}\text { Encouraging } \\
\text { investment is one of } \\
\text { the best ways to } \\
\text { solve affordable } \\
\text { housing as } \\
\text { investment laws } \\
\text { change according to } \\
\text { elected environments }\end{array}$ \\
\hline B5 & $\begin{array}{l}\text { (Lien, Laura Est } \\
\text { 2016) "Assessment } \\
\text { and analysis of } \\
\text { housing } \\
\text { accessibility: } \\
\text { adapting the } \\
\text { environmental } \\
\text { component of the } \\
\text { housing enabler to } \\
\text { United States } \\
\text { applications" }\end{array}$ & $\begin{array}{l}\text { Social and } \\
\text { accessibility } \\
\text { factors }\end{array}$ & $\begin{array}{l}\text { Because of the } \\
\text { problem of } \\
\text { disability in how to } \\
\text { reach homes }\end{array}$ & $\begin{array}{l}\text { Related to the } \\
\text { concept of } \\
\text { housing } \\
\text { satisfaction } \\
\text { and housing } \\
\text { standards }\end{array}$ & $\begin{array}{l}\text { The study adopted } \\
\text { specific } \\
\text { measurement } \\
\text { measures to achieve } \\
\text { the principle of } \\
\text { arrival, and } \\
\text { quantitative } \\
\text { measurement, which } \\
\text { is one of the best } \\
\text { methods adopted to } \\
\text { show the results of a } \\
\text { particular } \\
\text { experiment. }\end{array}$ \\
\hline B6 & $\begin{array}{l}\text { (Christian A. L et } \\
\text { al., 2016) "Housing } \\
\text { Policy in } \\
\text { Switzerland, UK } \\
\text { and USA". }\end{array}$ & $\begin{array}{l}\text { Political and } \\
\text { security factors }\end{array}$ & $\begin{array}{l}\text { Housing policy } \\
\text { lessons in a } \\
\text { developed country } \\
\text { are one of the most } \\
\text { important drivers } \\
\text { for housing policy } \\
\text { development in the } \\
\text { Middle East. }\end{array}$ & $\begin{array}{l}\text { Programs and } \\
\text { strategies }\end{array}$ & $\begin{array}{l}\text { Using the experience } \\
\text { of developed } \\
\text { countries in finding } \\
\text { solutions to housing } \\
\text { problems in Iraq, } \\
\text { taking into account } \\
\text { social standards to } \\
\text { achieve this goal }\end{array}$ \\
\hline B7 & $\begin{array}{l}\text { (Xin Liu et al., } \\
\text { 2016) "Exploring } \\
\text { the Problems of } \\
\text { Quality Housing } \\
\text { Design in China." }\end{array}$ & $\begin{array}{l}\text { Economic and } \\
\text { planning } \\
\text { factors }\end{array}$ & $\begin{array}{l}\text { Understand the } \\
\text { challenges of } \\
\text { improving the } \\
\text { quality of housing } \\
\text { design in China. }\end{array}$ & $\begin{array}{l}\text { Housing } \\
\text { problems and } \\
\text { housing } \\
\text { standards, } \\
\text { programs and } \\
\text { strategies } \\
\end{array}$ & $\begin{array}{l}\text { Examining the most } \\
\text { important elements } \\
\text { for improving design } \\
\text { quality and } \\
\text { identifying variables } \\
\text { and causes }\end{array}$ \\
\hline B8 & $\begin{array}{l}\text { (Rachel M .N. et } \\
\text { al., 2019) } \\
\text { "Assessing } \\
\text { Resilient Aspects in } \\
\text { the Housing Sector } \\
\text { to Overcome } \\
\text { Housing Stress in } \\
\text { Northern Iraq." }\end{array}$ & $\begin{array}{l}\text { Economic } \\
\text { factors and } \\
\text { planning } \\
\text { factors }\end{array}$ & $\begin{array}{l}\text { This study aims to } \\
\text { assess the } \\
\text { sustainability } \\
\text { aspects } \\
\text { (environmental, } \\
\text { economic and } \\
\text { social) of the } \\
\text { housing sector. }\end{array}$ & $\begin{array}{l}\text { Housing } \\
\text { Problems, } \\
\text { Housing } \\
\text { Standards, } \\
\text { Programs and } \\
\text { Strategies. }\end{array}$ & $\begin{array}{l}\text { Achieving a balance } \\
\text { between social and } \\
\text { economic standards } \\
\text { in residential } \\
\text { buildings in } \\
\text { accordance with the } \\
\text { adaptation criteria }\end{array}$ \\
\hline
\end{tabular}


Table 3. Summarizing research on informal housing

\begin{tabular}{|c|c|c|c|c|c|}
\hline Index & Study & $\begin{array}{l}\text { Related } \\
\text { Factors }\end{array}$ & $\begin{array}{l}\text { Causes of the } \\
\text { Phenomenon }\end{array}$ & $\begin{array}{l}\text { Related } \\
\text { Concepts }\end{array}$ & Research Notes \\
\hline $\mathrm{C} 1$ & $\begin{array}{l}\text { (Adekoyejo Est, 2017) } \\
\text { "Emergence of Informal } \\
\text { Housing: Implications for } \\
\text { Development of Low- } \\
\text { Cost Housing Delivery } \\
\text { Strategies in Abeokuta, } \\
\text { Nigeria" }\end{array}$ & $\begin{array}{l}\text { Economic } \\
\text { factors and } \\
\text { building } \\
\text { strategies }\end{array}$ & $\begin{array}{l}\text { High property } \\
\text { prices in city } \\
\text { centers }\end{array}$ & $\begin{array}{l}\text { Related to } \\
\text { the concept } \\
\text { of } \\
\text { formation } \\
\text { problems } \\
\text { and decent } \\
\text { housing } \\
\text { standards }\end{array}$ & $\begin{array}{l}\text { Testing the } \\
\text { housing } \\
\text { strategies in the } \\
\text { study area and } \\
\text { diagnosing the } \\
\text { objective } \\
\text { solutions }\end{array}$ \\
\hline $\mathrm{C} 2$ & $\begin{array}{l}\text { (Nabil Taha, 2010) " The } \\
\text { Informal Areas and the } \\
\text { ways Treated it with } \\
\text { Planning Standard for } \\
\text { Residential Areas" }\end{array}$ & $\begin{array}{l}\text { Environmental } \\
\text { factors, } \\
\text { planning } \\
\text { factors and } \\
\text { standards- } \\
\text { related factors }\end{array}$ & $\begin{array}{l}\text { Increasing the } \\
\text { size of families } \\
\text { and economic } \\
\text { conditions and } \\
\text { the desire to own } \\
\text { a housing unit }\end{array}$ & $\begin{array}{l}\text { Related to } \\
\text { housing } \\
\text { problems } \\
\text { as well as } \\
\text { to adopted } \\
\text { programs } \\
\text { and } \\
\text { policies } \\
\end{array}$ & $\begin{array}{l}\text { Dealing with } \\
\text { informal houses } \\
\text { as a needing and } \\
\text { a housing } \\
\text { balance }\end{array}$ \\
\hline $\mathrm{C} 3$ & $\begin{array}{l}\text { (Hanan Mahmoud, 2008) } \\
\text { "The phenomenon of } \\
\text { random housing in some } \\
\text { Arab cities, an analytical } \\
\text { study of the causes of } \\
\text { emergence and planning } \\
\text { scenarios of the } \\
\text { possibilities of treatment" }\end{array}$ & $\begin{array}{l}\text { Economic } \\
\text { factors, social } \\
\text { factors and the } \\
\text { way resources } \\
\text { are managed }\end{array}$ & $\begin{array}{l}\text { Unprogrammed } \\
\text { planning and } \\
\text { non-realistic } \\
\text { solutions to } \\
\text { existing } \\
\text { problems }\end{array}$ & $\begin{array}{l}\text { Related to } \\
\text { housing } \\
\text { problems, } \\
\text { as well as } \\
\text { to adopted } \\
\text { programs } \\
\text { and } \\
\text { policies }\end{array}$ & $\begin{array}{l}\text { An experienced } \\
\text { Arab's } \\
\text { experiences } \\
\text { represent a basis } \\
\text { for dealing with } \\
\text { informal } \\
\text { housing, taking } \\
\text { into account the } \\
\text { specific } \\
\text { environment }\end{array}$ \\
\hline $\mathrm{C} 4$ & $\begin{array}{l}\text { (Haidar Attia, 2014) " } \\
\text { The Spatial Analysis of } \\
\text { Random Residence } \\
\text { Phenomenon Reality } \\
\text { in Al-Kufa City " }\end{array}$ & $\begin{array}{l}\text { Social factors } \\
\text { and criteria for } \\
\text { planning }\end{array}$ & $\begin{array}{l}\text { The acute } \\
\text { shortage of } \\
\text { housing, absence } \\
\text { of laws, its } \\
\text { application, and } \\
\text { commercial } \\
\text { speculation }\end{array}$ & $\begin{array}{l}\text { Related to } \\
\text { the concept } \\
\text { of problem } \\
\text { prospects } \\
\text { and the } \\
\text { concept of } \\
\text { standards }\end{array}$ & $\begin{array}{l}\text { The theme of } \\
\text { random } \\
\text { neighborhoods is } \\
\text { no less important } \\
\text { than other } \\
\text { official } \\
\text { neighborhoods in } \\
\text { terms of physical } \\
\text { characteristics } \\
\text { and geographical } \\
\text { location }\end{array}$ \\
\hline $\mathrm{C} 5$ & $\begin{array}{l}\text { (Miguel Amado Est } \\
\text {,2018) } \\
\text { 'TRANSFORMATION } \\
\text { OF INFORMAL } \\
\text { SETTLEMENTS: CASE } \\
\text { OF CAPE VERT' }\end{array}$ & $\begin{array}{l}\text { Standards and } \\
\text { principles of } \\
\text { urban planning }\end{array}$ & $\begin{array}{l}\text { The lack of } \\
\text { clarity of land } \\
\text { ownership is one } \\
\text { of the reasons } \\
\text { for the increase } \\
\text { in informal areas }\end{array}$ & $\begin{array}{l}\text { Related to } \\
\text { future } \\
\text { prospects } \\
\text { to resolve } \\
\text { the } \\
\text { problem }\end{array}$ & $\begin{array}{l}\text { The design of a } \\
\text { program that } \\
\text { helps in } \\
\text { identifying, } \\
\text { distributing and } \\
\text { clarifying land } \\
\text { ownership is one } \\
\text { of the reasons for } \\
\text { the increase in } \\
\text { informal areas }\end{array}$ \\
\hline C6 & $\begin{array}{l}\text { (Yue Zhang,2017) The } \\
\text { credibility of slums: } \\
\text { Informal housing and } \\
\text { urban governance in India }\end{array}$ & $\begin{array}{l}\text { Economic } \\
\text { factors as well } \\
\text { as principles of } \\
\text { urban planning } \\
\text { and policies }\end{array}$ & $\begin{array}{l}\text { Informal } \\
\text { neighborhoods } \\
\text { have proven } \\
\text { their credibility } \\
\text { through } \\
\text { economic, } \\
\text { political and } \\
\text { housing } \\
\text { opportunities. }\end{array}$ & $\begin{array}{l}\text { Programs, } \\
\text { policies } \\
\text { and } \\
\text { standards }\end{array}$ & $\begin{array}{l}\text { Formalizing } \\
\text { informal } \\
\text { neighborhoods } \\
\text { through } \\
\text { government } \\
\text { programs to } \\
\text { provide } \\
\text { credibility }\end{array}$ \\
\hline
\end{tabular}


Table 3. Continued

\begin{tabular}{|c|c|c|c|c|c|}
\hline C7 & $\begin{array}{l}\text { (Paula Meth ,2017) } \\
\text { INFORMAL HOUSING, } \\
\text { GENDER, CRIME AND } \\
\text { VIOLENCE: THE ROLE } \\
\text { OF DESIGN IN URBAN } \\
\text { SOUTH AFRICA }\end{array}$ & $\begin{array}{l}\text { Planning, } \\
\text { design and } \\
\text { security, } \\
\text { political and } \\
\text { social factors }\end{array}$ & $\begin{array}{l}\text { Excessive } \\
\text { permeability of } \\
\text { residential } \\
\text { structures is the } \\
\text { biggest problem } \\
\text { in generating } \\
\text { violence and } \\
\text { crime. }\end{array}$ & $\begin{array}{l}\text { The } \\
\text { concept of } \\
\text { residential } \\
\text { problems } \\
\text { residential } \\
\text { programs } \\
\text { and } \\
\text { residential } \\
\text { standards }\end{array}$ & $\begin{array}{l}\text { It addresses the } \\
\text { treatment of } \\
\text { crime and } \\
\text { violence through } \\
\text { housing } \\
\text { programs, } \\
\text { redesign and } \\
\text { resettlement in } \\
\text { informal } \\
\text { neighborhoods. }\end{array}$ \\
\hline
\end{tabular}

\subsection{Analyze and discuss the results}

The factors and concepts that make up the residential architectural environment are identified, determined by seven factors and six concepts, Table (4) This was done using previous studies that show the extent of its impact and its relationship with the residential environment. The process of formulating the results was done by knowing the degree of relationship of each concept and each factor with the living environment, where the results and available knowledge were interrupted by three groups of studies that were accepted in the study, namely (studies related to the formation of a residential architectural environment, studies related to housing standards, problems, policies and research related to informal housing), it was found that there is a need to reformulate and define the residential architectural environment, knowing the degree of connection (between the residential architectural environment and factors and specific concepts), This relationship is divided into three levels (1-strong correlation with degree 2, 2-average correlation with degree 1.3-weak correlation with degree 0). This explains the levels of concepts and factors involved in redefining and articulating a living environment capable of providing a better quality of life for its inhabitants.

Table 4. The most important factors and concepts related to the residential architectural environment.

\begin{tabular}{|c|}
\hline Influencing Factors \\
\hline Social and cultural factors \\
\hline Economic forces \\
\hline Environmental and climatic factors \\
\hline Geographic factors \\
\hline Political and security factors \\
\hline Subjective or psychological factors \\
\hline Planning factors \\
\hline
\end{tabular}

\begin{tabular}{|c|}
\hline Related concepts \\
\hline Concept Architectural formation \\
\hline Housing problems \\
\hline Residential standards \\
\hline Housing satisfaction and decent housing \\
\hline Programs and strategies \\
\hline Identity and transformation \\
\hline \\
\hline
\end{tabular}

\subsection{Methods for achieving the satisfaction of residents with elements of the living environment}

Research is a model and strategic research for reformulating the architectural environment based on the vocabulary of this environment, determined by that time by the preparation of theoretical foundations based on two concepts of knowledge related to the subject of our research (problems of architectural configuration) and (shaping the prospects for possible solutions). If research shows that the process of connecting to any habitat depends on the nature of the environment chosen in terms of the quality of daily life and the most appropriate housing schemes, and the other party determines the incentives and housing standards based 
on the availability of economic opportunities to meet housing needs, thereby providing the population with more opportunities (Fig. 1).

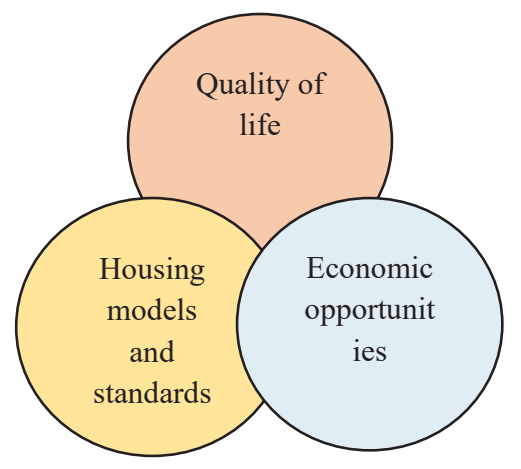

Fig. 1. Scheme for determining criteria for satisfaction with housing

\subsection{Redefining Residential Architecture in Iraq}

A residential architectural environment can be defined as a social activity for individuals or a society with residential elements that make up an environment based on social norms and traditions, in accordance with modern conditions and requirements, as well as constant changes in intellectual products that are formed in the human mind ... And thus, reflecting on the behavior of people on a daily basis and based on this research, a new definition of the architectural environment can be developed: as an urban context that depends on the sociocultural economic context of specific environmental conditions and in accordance with standards and models. Housing is based on systems and laws and programs that are sustainable taking into account the requirements of modern life, the population. And thus, access to socially acceptable housing, providing the concept of decent housing or housing satisfaction. (Fig. 2).

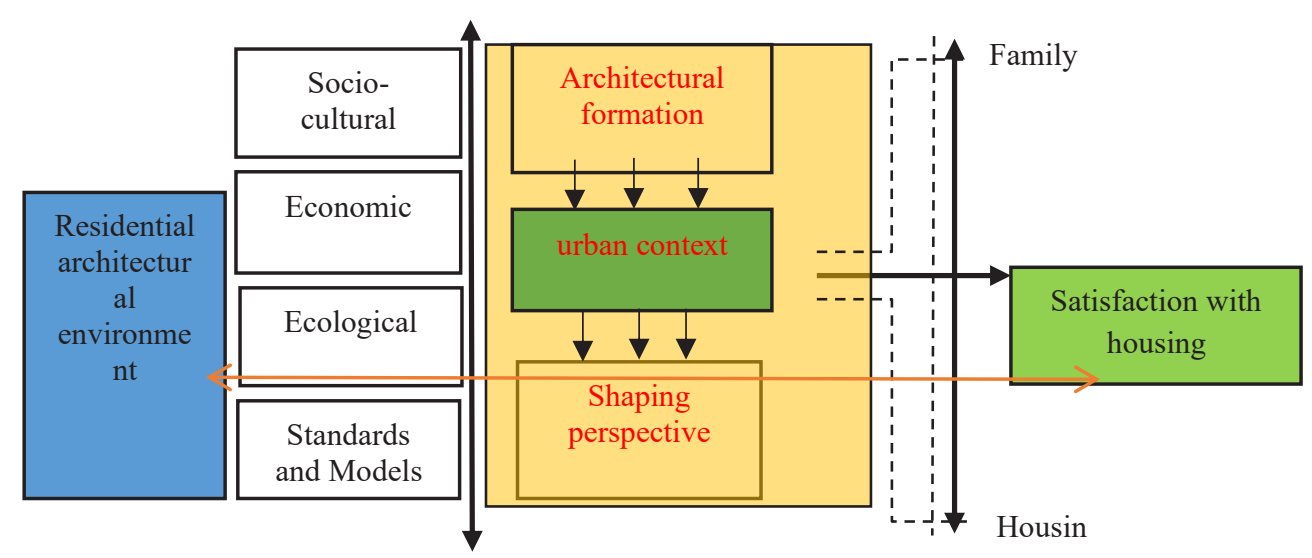

Fig. 2. Scheme for determining criteria for satisfaction with housing

\section{Conclusion}

1. The main stages and patterns of development of the architecture of the residential environment in Iraq have been identified (1. the formation of the residential architectural 
environment. 2. The criteria for satisfaction with housing or socially acceptable housing. 3 . Informal housing). By rethinking the architectural environment in Iraq, which includes a set of factors that make a living environment acceptable to Iraqis by conducting and analyzing global, regional

2. Examination of the existing literature has shown that the research available in Iraq is scarce and of low quality, since it does not use modern research methodology that could cover the living environment in different aspects and from different points of view. The most important factors that are related to the problems of the living environment are reflected in the realities of the country, as well as in informal or casual housing, which requires close examination.

3. Previous research develops social patterns after working with architectural environments in which the researcher can choose the best way to solve the problem of the elite living environment from certain aspects of the research. This is consistent with behavior, customs and social traditions and understanding of other aspects of tension, divided into economic, political and natural aspects of security.

4. The study presents a summary of cognitive trends from previous works through their main observations and analysis, which in the future can become a guideline in the preparation of a theoretical framework that determines the main research problem. The study identified factors that influenced the architectural environment in the public sphere, which are divided according to objective directions, which can be understood by three basic concepts (Satisfaction with housing, urban context, architectural formation). They are related to objective reasons for the various residential environments considered in the study. These equations and factors created architectural concepts and research formulas that can be adopted to understand the broader residential architectural environment. It is very important to determine the criteria on the basis of which decisions are formed for specific forms of the living environment, which would reflect the life of the population.

\section{References}

1. M. Yaqub, Open Source Architecture: Redefining Residential Architecture in Islamabad, School of Architecture, Art, and Historic Preservation Theses and Projects, 28 (2017)

2. O. Al-hafith, B. K. Satish, S. Bradbury and P. D. Wilde, Front. Archit. Res., 24, 3 (2018)

3. T. V. Zaitseva, Adaptation of the residential environment of micro-districts of mass typical building to modern socio-economic processes, 127 (2017)

4. Zh. B. Shahin, Conditions for the formation of low-rise residential buildings for highdensity urban development (on the example of Iraq), 23 (1993)

5. A. Ghaffarianhoseibi, U. Berardi, N. D. Dahland, The Essence of Malay Vernacular Houses: Analysis of the Socio-Cultural, 156 (2014)

6. M. Irani, P. Armstrong, A. Rastegar, Asian Cult. Hist., 9(2), 46 (2017)

7. A. D. Jiboye, Front. Archit. Res., 3(1), 20 (2014)

8. A. Akalin, K. Yildirim, C. Wilson, O. Kilicoglu, J. Environ. Psychol., 29(1), 124 (2009)

9. Al-fadillh $\mathrm{m}$. Th., The social influence of the changment of the house form (Baghdad city ) (2005)

10. I. V. Zhdanova, Architectural methods for assessing and improving the consumer properties of the housing environment, 29 (2013)

11. P. Tiwari, J. Rao, Housing Markets and Housing Policies in India (2016)

12. P. Onyemaechi, M. Samy, Mediterr. J. Soc. Sci., 7(2), 149 (2016)

13. A. J.Huda, National Housing Policies in Iraq- A Comparative Study (2015) 
14. K. A. Ali, L. M. Raswol, ZANCO J. Pure Appl. Sci., 28, 342 (2017)

15. L. L. Lien, C. D. Steggell, B. Slaug, S. Iwarsson, J. Hous. Built Environ., 31(3), 565 (2016)

16. C. Q. L. Xue, Habitat Int., 57, 242 (2016)

17. Rahel, M. Amin, S. Salah, Contemp. Urban Aff., 3(1), 67 (2019)

18. C. A. L. Hilber, O. Schöni, The Housing Challenge in Emerging Asia: Options and Solutions., 210 (Japan, 2016)

19. B. Adekoyejo, A. Olatunde, Int. J. Innov. Res. Dev., 6(3) (2017)

20. M. Amado, F. Poggi, A. Martins, N. Vieira, A. R. Amado, Creat. Commons CC BY, 18, 1 (2018)

21. H. M. Al-juboury, The Phenomenon of Informal Settlements in Some of Arabic Cities (2008)

22. N. Taha, The Informal Areas and the ways Treated it with Planning Standard for Residential Areas (2010)

23. Al-Garaawi Hayder Atiya Abd Nasir, The Spatial Analysis of Random Residence phenomenon Reality in Al-Kufa City (2014)

24. Y. Zhang, Land Use Policy The credibility of slums: Informal housing and urban governance in India, 1 (2017)

25. P. Meth, Brit. J. Criminol, 57, 402 (2017) 